\title{
Factors that Influence Men and Women Participation in Microcredit Programme in Lagos State, Nigeria: A Case Study of Cowries Microfinance Bank (CMD)
}

\author{
Adijat Olubukola Olateju \\ Faculty of Social Sciences, Department of Economics, \\ Lagos State University, Ojo, Lagos, Nigeria
}

Doi: 10.19044/esj.2018.v14n13p75 URL:http://dx.doi.org/10.19044/esj.2018.v14n13p75

\begin{abstract}
Financial inclusion is paramount for economic growth, economic development, job creation, and poverty reduction. Evidence has shown that to ensure financial inclusion policy measures and developmental programmes need to be country specific and should be based on individual country's gender gap. Given this, this study examined the factors that determine men and women entrepreneurs' access to microcredit programme in Lagos State, Nigeria. A total of 359 female micro-entrepreneurs and 191 male microentrepreneurs were selected through a simple random sampling method among the customers of Cowries Microfinance Bank (CMB). Data were analysed with descriptive statistics and logistic regression. The results of the logistic regression show that only four of the variables used in measuring the determinants of participation in the credit programme were significant for the male entrepreneurs while for the female entrepreneurs, almost all the variables were significant except the age variable of the respondents. It is therefore, recommended that policymakers, microfinance banks, NGOs are advised to consider the age, number of years of education, political involvement and experience of the male entrepreneurs when granting loan facility to the male. However, for the female entrepreneurs, policymakers should take cognizance of the marital status, years of education, experience acquired in the business, size of the household, political membership, and level of income when providing credit facilities to the female entrepreneurs. Consequently, this will help to ensure that loan facility is given to the right person so that the gender gap regarding credit accessibility are closed, thereby leading to economic growth and sustainable economic development.
\end{abstract}

Keywords: Banking, gender equality 


\section{Introduction}

In Nigeria, microenterprises business is one of the business activities engaged in by both men and women due to the high unemployment rate, high poverty level, and difficulties often encountered by entrepreneurs when accessing credit from conventional financial institutions in terms of stringent documentations and collateral requirements. Also, the fact that microenterprises activities in most cases often require small capital; this usually encourages entrepreneurs (both men and women) to engage in these activities.

Available statistics indicate that the numbers of male and female entrepreneurs in Nigeria that engage in microenterprises business are often very high. For instance, according to 2010, NBS Survey, out of the 13,563, 427 persons that were involved in microenterprises business activities in Nigeria, 6,044379.19 (44.56\%) are male, while 7,519,047.97 (55.44\%) are female (National Bureau of Statistic (NBS) Survey, 2010).

In spite of the substantial involvement of male and female in microenterprises activities in Nigeria, capital has always been an impediment to business growth and expansion of entrepreneurs. Studies have shown that financial exclusion most especially in the realm of access to finance could result in poverty trap and inequality (Aghion and Bolton 1997; Banerjee and Newman 1993; Galor and Zeira 1993;). Also, the inability to gain access to credit has been emphasised as a factor that makes it difficult for men and women to expand from small-scale business activities to large-scale activities (Jeyol, Akpan, \& Tee 2013).

Furthermore, the number of financially excluded person is still on the high side for both male and female in Nigeria. For instance, from the Enhancing Financial Inclusion and Access (EFinA) Survey in 2014, it was discovered that $42.7 \%$ of the total females population are financially excluded, while $36.8 \%$ of the total males population are financially excluded (EFinA Survey, 2014).

However, it is noted that policy measures to increase financial inclusion need to be country-specific and also focus on a country's gender gap (Alliance for Financial Inclusion - AFI, 2016). In spite of the various developmental policies carried out by different governments in Nigeria to reduce gender gap, little attention has been placed on the factors that determine credit participation between gender; as most studies often look at the respondents generally without looking at the gender aspect. Also, some few studies that examined the gender aspect of the factors that influence credit participation often concentrate their analysis on women alone (Anjugam, \& Ramasamy, 2007; Anyiro et al., 2017; Kifle et al., 2013: Bhoj et al., 2013; Shah, and Panigrahi, 2015); this is because it is often believed that women participate more in microcredit programme than their male counterpart. Also, 
women are considered to be more vulnerable to poverty due to their domestic role, reproductive role, and gender stereotype that often impede their business activities.

However, it should be noted, that what determines credit participation could differ between genders due to individual characteristics that could affect participation. Furthermore, the gap between female entrepreneurs and male entrepreneurs' participation in microenterprises in Nigeria is not too wide for the male entrepreneurs to be ignored. This is because both male and female have a high percentage of participants in microenterprises activities due to the high poverty rate, lack of employment opportunities, stringent collateral securities that are often required by some conventional banks and strict documentation that are required when accessing loan from conventional banks in the country.

Given this, this study intends to identify the factors that determine men and women participation in Cowries microcredit Bank's programme in Lagos State, Nigeria. Therefore, the information that will be gathered from the result of this study will be useful for microfinance banks' practitioners, policymakers, and government as regards what they need to consider when extending loan facility to entrepreneurs. Besides this, the study will also assist in providing information that will help to close the gender gap in terms of financial inclusion, as a high financial inclusion for both male and female in any economy is paramount in order to ensure economic growth, economic development, poverty reduction, and employment generation.

Sequel to the introductory part of this study, the next section is the literature review. The third section is the research methodology, while the fourth section presents the result, findings, and discussion. Finally, Section five concludes the study, gives some recommendations, and suggestion for further study.

\section{Literature review}

Studied on the factors that determine access to credit are many in the literature (Ajagbe, Oyelere, \& Ajetomobi, 2012; Balogun, \& Yusuf, 2011; Daniel, Job, \& Ithinji, 2013; Duflo, 2008; Kifle, et al. 2013; Shan, Hashimi, \& Bukhari, 2008). in spite of the many literature that exists on the factors that influence access to credit only few of these studies examine the gender aspect of these factors. Also, the few studies that looked at the gender part often based their analysis on women; as women are considered to be more vulnerable to poverty (as found in the studies by Anjugan \& Ramasamy, 2013; Bhoj, Bardhan \& Kumar, 2013; Kifle et al. 2013),

Peprah (2012) found in a study in Ghana that the well-being of the clients and their business experience influence their credit accessibility. The author, however, found that the marital status and the educational level of the 
client did not affect their access to credit. In a recent study, Kiplimo et al., (2015) found in Kenya a statistically significant and positive effect of education, occupation, and access to extension services, as determinant factors of access to financial service for smallholder farmers.

However, in an earlier study, Sailot (2011) used both qualitative and quantitative technique to determine women entrepreneurs' access to credit and found the business experience, size of business, educational level, age, and the capital invested in the business as factors that determine access to credit facility in Toi market, Nairobi County. Anjugan \& Ramasamy (2013), concentrate on the determinants of women's participation in a self-Help Group (SHG) - led microfinance programme in Tamil Nadu, India. The study found through a probit model that the age of the women and value of productive assets (apart from land) have a significant negative impact on their involvement in the microfinance programme.

In another study, Bhoj, Bardhan \& Kumar, (2013) used both qualitative and quantitative data and found through logit model that the variables that significantly determine the membership of women in dairy SHGs are their age, educational level, income from non-farm, herd size, and proximity to a market place. Similarly, Kifle et al., (2013) used a probit regression to investigate the determinants of women's participation in microfinance services in rural Dare Dawa, Ethiopia. It was found that the monthly saving, the size of the family, and the number of land in hectares are the factors that significantly influence women participation in the programme.

However, some studies have analysed the factors that influence access to credit in term of the gender of the participants. For instance, in an earlier study by Mohamed \& Temu (2009), the authors used a probit regression to determine whether factors that influence rural household access to credit differ by gender of participants or not. The result of the probit regression indicates that male and female access to credit is affected by different factors. According to the authors, male credit asset is influenced by the market integration, wealth and risk bearing indicators while female decision to access credit is affected only by the household's income.

Similarly, Kitili (2012) examined the factors that influence access to credit by men and women in Mombasa County in Kenya. The author established that access to loan is highly determined by personal savings and business asset/stock for both genders. However, the author emphasized, the presence of gender disparities in the control of resources, lack of collateral, high cost of fund, religion influence (Islam), information asymmetric in the area of loan qualification requirement, and also mandatory requirement for women to bring their spouse/means of identification. The author concluded that there were gender disparities regarding credit accessibility. 
In another study of gender analysis of access to credit by rural smallscale farmers in Benue State, Nigeria Jeiyol, Akpan, \& Tee (2013), found that farmers' expenditure in the household, price of fertilizer expenditure on hired labour, size of the farmland, and income accrued from farm are significant factors that influence access to credit among male and female farmers.

Hence, from the few studies that are gender sensitive to the factors that influence access to credit, it can be vividly seen that there are disparities between factors that determine men and women access to microcredit. Therefore, the importance of gender sensitivity of this study is germane.

\section{Methodology}

\section{a) Area of Study}

The study was carried out in Lagos State, Nigeria. Lagos State was selected out of the thirty-six States in Nigeria, because of the high number of microenterprises, high population, high commercial activities which are all in converse to the high poverty level. Also, the state has a high number of men and women that engage in entrepreneurial activities with more women taking part in such activities than men; nevertheless, the gap is not too wide.

\section{b) Sources of Data and Area of Study}

The data for the study were collected randomly from the customers of the case study bank (Cowries Microfinance Bank - CMB), and this includes both men and women entrepreneurs, for the men a total of 191 were randomly selected and this comprises of both participants and non-participant in the programme. And for the female, 359 entrepreneurs were selected which is also made up of both participant and non-participant entrepreneurs.

Cowries Microfinance Bank (CMD) was preferred among other microfinance in the State because of its alliance with Lagos State Microfinance Institution (LASMI); which focuses on giving loan to entrepreneurs in order to reduce poverty. Also, unlike some microfinance banks that focus mainly on women, this bank's credit activities cover both men and women entrepreneurs.

\section{c) Model Specification and Estimation Procedures}

Factors that influence access to microcredit have been conceptualized in the literature in different ways by different studies. Some of these factors are often based on the characteristics of the loan beneficiary, examples of these are household characteristics, demographic characteristics, demand side (household/client/customers). Others are based on the non-beneficiary of the loan, and these are the supply-side (lenders) factors and institutional factors. However, in line with Mohamed, (2003); Yusuf, Shirazi, and Ghani (2013), this study used both demographic and socio-economic characteristics of the male and female entrepreneurs as factors that determine their access to microcredit programme in Lagos State, Nigeria. These demographic characteristics are age, marital status, and household size, while the socio- 
economic characteristics are years of schooling, business experience, membership of a political party, and extra income earn by the entrepreneurs. Based on these factors our model is specified as:

$\mathrm{Y}=\mathrm{f}(\mathrm{X} . \mathrm{U})$

$$
\mathrm{Y}=\alpha_{0}+\alpha \mathrm{X}_{\mathrm{Ei}}+\mathrm{U}
$$

Where $\mathrm{Y}$ is the binary or dichotomous variable and represents the entrepreneur's decision to access $(=1)$ microcredit or not to access $(=0)$ microcredit. This dependent variable $\mathrm{Y}$ also depends on some vector of entrepreneurs' demographic characteristics and socio-economic characteristics. Therefore,

$\alpha=$ Constant term in the equation

$\mathrm{X}_{\mathrm{Ei}}=$ Vectors of entrepreneurs' characteristics (comprises both demography and

socio-economic characteristics of the entrepreneurs) and these are given as;

$\mathrm{X}_{\mathrm{E} 1}=\mathrm{age}$

$\mathrm{X}_{\mathrm{E} 2}=$ Marital status

$\mathrm{X}_{\mathrm{E} 3}=$ Income

$\mathrm{X}_{\mathrm{E} 4}=$ Number of years spent in education

$\mathrm{X}_{\mathrm{E} 5}=$ Membership in a political party

$\mathrm{X}_{\mathrm{E} 6}=$ Household size

$\mathrm{X}_{\mathrm{E} 7}=$ Experience

$\mathrm{U}=$ Error terms

Since the outcome/explanatory variable is a binary response variable, the empirical analysis of the factors that determine access to CMB credit programme was carried out with a logit model. The logit model is stated as; $\operatorname{Pr}\left(\mathrm{Y}_{\mathrm{nj}}=1\right)=\frac{1}{[1+\exp -(\delta+\beta \mathrm{j} X n \mathrm{j})]}$ equation 2

From equation $2, \delta$ is the intercept of the equation and also the constant term, $\beta \mathrm{j}$ represents the vector of the coefficients for the explanatory variable $\mathrm{X}, \mathrm{Y}$ is the outcome variable which represents 1 for access and 0 for otherwise. The Pr in the equation is the probability of the entrepreneur's access to CMB credit programme.

The $B_{j}$ coefficient in Equation 2 above is difficult to interpret because the equation is a cumulative logistic distribution function which is in a nonlinear form. To transform the equation into a linear form, for easy interpretation of the coefficients, the equation is stated in terms of log-odds ratio (Madala, 2001). The interpretation of the coefficient is done using the odds ratio which is determined from the probabilities; the odd ratio of access, for instance, is the ratio of the probability of access to the probability of no access. Thus, the equation is stated below after transformation into a linear form: 
$\log [\operatorname{Pr}(Y=1)]=\log \left[\frac{\operatorname{Pr}}{1-\operatorname{Pr}}\right]=\delta+\beta \mathrm{jXnj}$ ....... Equation 3

The logistic regression is estimated with the use of Maximum Likelihood (ML) estimator (Wooldridge, 2002). This study chooses the logistic model because of its simplicity, ease of calculation, and its nonrigidity (Sirak \& Rice, 1994).

\section{Result, Findings, and Discussion}

\section{a) Descriptive Statistics}

From the descriptive statistics analysis in Table 1 below, for the male category, only $67(36.08 \%)$ out of the total male respondents of 191 participated in the programme and the remaining 124 (64.92\%) was not involved in the programme. For the female category, however, more than half which is $183(50.97 \%)$ of the total 359 respondents were involved in the programme, while the rest $176(49.03 \%)$ did not include participants in the programme.

\begin{tabular}{|c|c|c|c|c|}
\hline \multirow[t]{2}{*}{ Variables } & \multicolumn{2}{|c|}{ Male } & \multicolumn{2}{|c|}{ Female } \\
\hline & Frequency & Percentage & Frequency & Percentage \\
\hline Treat: & & & & \\
\hline Participants & 67 & $(38.06)$ & 183 & $(50.97)$ \\
\hline $\begin{array}{l}\text { Non- participants } \\
\text { Age group: }\end{array}$ & 124 & $(64.92)$ & 176 & $(49.03)$ \\
\hline Active working Age & 121 & $(67.54)$ & 256 & $(71.31)$ \\
\hline $\begin{array}{l}\text { Non- active working age } \\
\text { Marital: }\end{array}$ & 62 & $(32,46)$ & 103 & $(38.69)$ \\
\hline Married & 107 & $(56.92)$ & 223 & $(62.12)$ \\
\hline $\begin{array}{l}\text { Single } \\
\text { Edu: }\end{array}$ & 84 & (43.96) & 136 & $(37.88)$ \\
\hline Literate & 181 & $(84.76)$ & 337 & $(93.87)$ \\
\hline illiterate & 10 & $(5.24)$ & 22 & $(6.13)$ \\
\hline Member political: & & & & \\
\hline Member & 124 & $(64.92)$ & 224 & $(62.40)$ \\
\hline Non-member & 67 & $(35.08)$ & 135 & $(37.60)$ \\
\hline
\end{tabular}

Source: Author's compilation

For the age group, the majority of the women entrepreneurs fall within their active working age group of 25-45 years, while few were outside the productive working age group. This is given by the frequency and the percentage as $256(71.31 \%)$ and $103(28.69 \%)$ for those within the active working age group and those outside the productive working age group respectively. Similarly, the majority of the men entrepreneurs fall within the active working age group of 25-45 years, and this is given by the frequency and the percentage as $129(67.54 \%)$ while the rest $62(32.46 \%)$ are not within the working age group. 
Furthermore, more than $60 \%$ of the women entrepreneurs were married $(62.12 \%)$ while the remaining $37.88 \%$ were not married. Also, for the male entrepreneurs, more than half of the male respondents are married, and this is given as $107(56.02 \%)$ while the remaining $84(43.98 \%)$ are not married. In term of education, almost all the women entrepreneurs were educated, and this is given by 337 (93.87\%) while just $22(6.13 \%)$ were not educated, the level of education for the women entrepreneurs falls within the level of primary, secondary, and Ordinary National Diploma (OND) levels of education. In the same vein, the majority of the male respondents are literate while just a few are illiterate and this is represented by $181(94.76 \%)$ and 10 (5.24\%) for the educated and non-educated male respondents respectively in Table 1.

In the realm of politics, most of the women entrepreneurs belong to one political party or the other and this is given as $224(62.40 \%)$ for those that are members of a political party while the rest 135 (37.60\%) are non-member of a political party. Also, for the male entrepreneurs, over $60 \%$ of the male respondents are members of a political party which is represented by the frequency and percentage of 124 and $64.92 \%$ respectively. However, the remaining 67 and $35.08 \%$ which represent the frequency and the percentage respectively are non-members of any political party.

B) Logistic Regression

Table2: Logistic Regression Result

Male:

Observation $=191$

LR Chi2(7) $=40.16$

Pro $>$ Chi $2=0.0000$

Pseudo R2 $=0.1623$
Female:

Observation $=359$

LR Chi2(7) $=84.88$

Pro $>$ Chi $2=0.0000$

Pseudo R2 = 0.1706

\begin{tabular}{|c|c|c|c|c|}
\hline \multirow[t]{2}{*}{ Variable } & \multirow{2}{*}{$\begin{array}{l}\text { Odd Ratios } \\
\text { Male } \\
\text { Female }\end{array}$} & \multirow{2}{*}{$\begin{array}{c}\text { P-value } \\
\text { Male } \\
\text { Female }\end{array}$} & \multicolumn{2}{|c|}{ Coefficient } \\
\hline & & & Male & Female \\
\hline Age & $\begin{array}{l}0.9539 \\
0.0166\end{array}$ & $0.052 \quad 0.279$ & $\begin{array}{c}-0.0472 * \\
(0.025)\end{array}$ & $\begin{array}{c}-0.0164 \\
(0.15)\end{array}$ \\
\hline marital & $\begin{array}{l}0.6055 \\
1.7053\end{array}$ & $\begin{array}{l}0.273 \\
0.030\end{array}$ & $\begin{array}{r}-0.5017 \\
(0.462)\end{array}$ & $\begin{array}{c}0.5337 * * \\
(0.251)\end{array}$ \\
\hline \multirow[t]{2}{*}{ Yr_edu } & $\begin{array}{l}0.8832 \\
0.8654\end{array}$ & $\begin{array}{l}0.003 \\
0.000\end{array}$ & \multicolumn{2}{|c|}{$\begin{array}{l}-0.1243 * * *- \\
0.1445 * * *\end{array}$} \\
\hline & & & $(0.044)$ & $(0.033)$ \\
\hline \multirow[t]{2}{*}{ no_yr_buss } & $\begin{array}{l}1.2736 \\
1.1215\end{array}$ & $\begin{array}{l}0.000 \\
0.002\end{array}$ & \multicolumn{2}{|c|}{$\begin{array}{l}0.2418 * * * \\
0.1147 * * *\end{array}$} \\
\hline & & & $(0.068)$ & $(0.039)$ \\
\hline
\end{tabular}




\begin{tabular}{cccc}
\hline hh-size & 0.9933 & 0.947 & $-0.0067 \quad-$ \\
& 0.8059 & 0.001 & $0.2158^{* * *}$ \\
Mem_political & & & $(0.101) \quad 0.071)$ \\
& 2.0587 & 0.048 & $0.6710^{* * * *}$ \\
Income & 1.9562 & 0.005 & $0.377) \quad(0.248)$ \\
& 0.9999 & 0.469 & $-5.6001 \quad-$ \\
& 0.9991 & 0.000 & $0.0021^{* * *}$ \\
& & & $(7.7701) \quad(5.360)$ \\
\hline
\end{tabular}

Standard error in parenthesis. Significant at $1 \%=* * * 5 \%=* * 10 \%=*$

\section{Age of the entrepreneur (age)}

The age variable which represents the age of the entrepreneurs is measured in years in Table 2. The variable shows that for every one unit change in the age, the log odds of accessing credit decrease by 0.0472 and 0.0164 for male and female respectively. For the odd ratio, a one unit increase in the variable age would decrease the odds of accessing credit in the programme by a factor of 0.9539 and 0.0166 for males and females entrepreneurs respectively.

The variable age is only significant at $10 \%$ for males; the significant value of the variable indicates that the age variable has a high influence on the male entrepreneurs in accessing credit. The variable is however not significant for the female entrepreneurs even at $10 \%$.

\section{Marital Status (marital)}

The marital status of the entrepreneurs which is represented by the variable marital of the entrepreneurs has a negative sign and insignificant coefficient for the male entrepreneurs. The variable is, however, positive and significant for the female. The significance value indicates that the marital status of the female entrepreneurs has a high influence on their access to the microcredit programme; this could be as a result of the fact that married female entrepreneurs are more likely to participate in the credit programme due to their domestic role, reproductive role, and cultural stereotype which often impede them from taking white-collar jobs.

The coefficient for the variable marital indicates that being married will reduce males' accessibility to the loan programme, while for the females, marriage will enhance their participation in the credit programme. This is given by the odd of the log which indicates that being married will decrease the $\log$ odds of access to the microcredit programme for the male entrepreneurs by 0.507 and increase the log-odds of female access to the programme by 0.5337 . The odd of accessing credit decreases by 0.6055 and increased by 1.7053 for male and female entrepreneurs respectively when the genders are married. 


\section{Year of education (yr_edu)}

The variable yr_edu which depicts the year of education of the entrepreneurs is highly significant and has a negative sign for its coefficients for both genders. The highly significant value means that the variable has a high impact in determining access to the credit programme for both genders. This implies that the more educated the respondents are the less likely they will want to participate in the programme, this is because their high education will give them more opportunities to get white-collar jobs.

The coefficient implies that for a one unit increase in the variable, the log odds of accessing credit will reduce by 0.1243 and 0.1445 for male and female entrepreneurs respectively. The odd ratio would change by 0.8832 and 0.8654 for every one unit change in yr_edu variable for both male and female entrepreneurs respectively while holding other variables constant.

\section{Experience (no_ yr_buss)}

The variable no_yr_ buss which is the experience acquired by an entrepreneur in the business has a positive sign and highly significant at $1 \%$ for both genders. This highly significant value of the variable indicates that the experience acquired by the entrepreneurs from the business has a high influence in determining their access to the microcredit programme.

The coefficient of the variable indicates that a one unit increase in the experience acquired by the entrepreneurs will increase the $\log$ odds of accessing credit by 0.2418 and 0.1147 for male and female entrepreneurs respectively. The odd ratio shows that for a one unit increase in the variable no_ yr_ buss, the odd of accessing credit in the program increase by a factor of 1.2736 and 1.1215 for male and female entrepreneur respectively.

\section{Number of people in the household (hh_ size)}

The hh_size variable which stands for the number of people living in a household has a negative sign for its coefficient for both genders but insignificant for the male gender. The variable is however, highly significant for the female entrepreneurs. The coefficient of the variable depicts that for a one unit increase in the variable, the log odds of accessing credit decreases by 0.0067 and 0.2158 for male and female entrepreneurs respectively. The odd of obtaining credit decreases by 0.9933 and 0.8059 for male and female entrepreneurs for every one unit increase in the number of people living in the household respectively.

\section{Member of political party (mem_ political)}

This variable mem_political, which signifies member of a political party is coded as 1 for being a member of a political party and 0 otherwise. 
The variable is positive for both genders and significant at $5 \%$ and $1 \%$ for male and female entrepreneur respectively.

The log-odds which are given by the coefficients of 0.7224 and 0.6710 for male and female entrepreneurs respectively, implies that being a member of a political party increases the log-odds of access to microcredit by 0.7224 and 0.6710 for male and female entrepreneur respectively. The odd ratio implies that for a one unit change in the variable mem_political the odd of having access to the credit programme increases by a factor of 2.0587 and 1.9562 for male and female entrepreneurs respectively.

\section{Additional income earned by the entrepreneur (Income)}

The variable income represents the extra income earned by the entrepreneurs. This variable is highly significant for the female entrepreneurs and insignificant for the male entrepreneurs even at $10 \%$. However, for both genders, the variable is negatively related to access to the credit programme.

The coefficient of the variable which is the log-odd shows that for every one unit increase in the additional income earned by the entrepreneur, the $\log$ odds of access to credit decrease by 5.6001 and 0.0021 for male and female entrepreneurs respectively. Furthermore, the odd would change by 0.999 and 0.9991 for male and female entrepreneurs respectively for every one unit change in the extra income received by the entrepreneurs while holding other variables constant.

\section{Conclusion and recommendation}

From the result it can be vividly seen that among the seven variable used by the study to determine the factors that influence access to Cowries Bank's microcredit programme in Amuwo Odofin and Ojo LGAs in Lagos State, Nigeria, only four of the variables were significant for the male entrepreneurs and these variables are age (age), number of years of schooling (yr_educ), experience in the business (no_yr buss) and membership of political (mem_political). Meanwhile, for the female entrepreneurs, almost all the variables were highly significant and these variables are number of years of schooling (yr- educ), experience in the business (no_yr buss) membership of political (mem_political), number of person in the household ( $\mathrm{hh} \_$size), and marital status of the respondents (married), and income level (income) except the age variable which is not significant even at $10 \%$. This implies that the gender of the respondents has a high influence on their accessibility to microcredit programme. Therefore, this study shows that the factors that determine participation in microcredit program differ between male and female entrepreneurs in the study area.

Since different factors influence access to microcredit in terms of gender of the participants, it is, therefore, suggested that policymakers, 
microfinance banks practitioners, and NGOs are advised to consider the age, number of years of education, political involvement and experience of the male entrepreneurs when given out loan to the male entrepreneurs. On the other hand, for the female entrepreneurs, they should take cognizance of the marital status, years of education of the female entrepreneur, experience in the business, the size of the household, political membership, and their level of income when providing credit facilities to the female entrepreneur, so that the impact of the credit in achieving a reduction in unemployment, poverty alleviation, sustainable growth, and economic development can be attained.

\section{Suggestion for Further Research}

It is advisable, that further study should consider other local government areas in Lagos State. Also, anecdotal evidence could be delved into by future research so that the result can be more robust and generalized for the state.

\section{References:}

1. Aghion, P., \& Bolton, P. (1997). ATheory of Trickle-Down Growth and Development. The

2. Review of Economic Studies, 64(2), 151-172.

3. Alliance for Financial Inclusion (AFI), 2016

4. Anjugam, M. \& Ramasamy,C (2007). Determinants of Women's Participation in Self-Help

5. Group (SHG)-Led Microfinance Programme in Tamil Nadu. Agricultural Economics Research Review, 20, 283 -298.

6. Anyiro, C. O. \& Oriaku, B. N. 2011. Access to and investment of formal microcredit by

7. smallholder farmers in Abia state, Nigeria. A case study of Absu microfinance bank, Uturu. Journal of agricultural science, 6(2), 69 76.

8. Anyiro, C.O., Ajuka, P.N., Emerole, C.O. \& Orji, I.E. (2014). Determinants of women's

9. participation in self-help group led micro-financing of farms in Isuikwuato Local Government Area of Abia State, Nigeria, Scientific Papers Series Management, Economic Engineering in Agriculture and Rural Development, 4(3). 21- 29.

10. Banerjee, A. V., \& Newman, A. (1993) Occupational Choice and the Process of development.

11. Journal of Political Economy, 101(2), 274 -98

12. Bhoj, S., Bardhan, D., \&Kumar, A. (2013). Determinants and implications of rural women's 
13. participation in microfinance programme: An analysis of dairy selfhelp groups in Uttarakhand State of India, Livestock Research for Rural Development, 25(10).

14. EFinA Survey, (2014). EFInA Access to Financial Services in Nigeria 2014 Survey

15. Galor, O., \& Zeira, J. (1993). Income distribution and macroeconomics. Review of Economic Studies, 60(1), 35 -52.

16. Jeiyol, E. N., Akpan, S. B., \& Tee, A. T. (2013). Gender Analysis of Access to Credit by Rural

17. Small Scale Farmers in Benue State, Nigeria. American International Journal of Social Science 2(6), 70 -78.

18. Kifle1, D., Tadesse,Y., Belay, S., \& Yousuf, J.y (2013). Determinants of women's participation in microfinance services: empirical evidence from Rural Dire Dawa, Ethiopia. African Journal of Agricultural Economics and Rural Development 1 (1), 001-007.

19. Kiplimo, J. C., Evans Ngenoh, E., Koech, W., \& Jullius K (2015). Determinants of Access to

20. Credit Financial Services by Smallholder Farmers in Kenya. Journal of Development and Agricultural Economics, 303 -313.

21. Kitili (2012).Factors influencing access to credit facilities among small and medium entrepreneurs in Island division, Mombasa county. Research report submitted to the school of humanities and social sciences 2012 Kenyatta University

22. Maddala, G. S. (2001). Introduction to Econometrics. Third Edition, Illustrated. Wiley

23. Majumder, M. H. (2008). Socio-Economic impact of microcredit in Bangladesh: a critical evaluation of the microcredit program of Grameen Bank. Unpublished $\mathrm{PhD}$ thesis University of Rajshahi, Bangladesh.

24. Mohamed, K. (2003). Access to formal and quasi-formal credit by smallholder farmers and artisan fishermen: a case of Zanzibar. Dar es Salam, Tanzania. Research on poverty Alleviation (REPOA).

25. Mohamed, K. S., \& Temu, A. E. (2009). Gender characteristics of the determinants of access to formal credit in rural Zanzibar. Savings and Development, 33(2), 95 -111.

26. NBS \& SMEDAN, (2010). Survey Report on Micro, Small and Medium Enterprises (MSMEs) In Nigeria. Abuja: NBS \& SMEDAN

27. Peprah, J. A. (2012). Access to micro-credit well-being among women entrepreneurs in the Mfantsiman Municipality of Ghana. International Journal of finance and banking studies, 1(1).

28. Sailot, K. (2011). A survey of the determinants of access to credit by women entrepreneurs in 
29. Toi market, Nairobi County. University of Nairobi Jomo Kenyatta Memorial Library.Retrieved: http://erepository.uonbi.ac.ke:8080/xmlui/handle/123456789/12615

30. Sarkar, A. R. (2000). Women in microcredit and their empowerment-Case study of BRAC societies under Sherpur Upazila of Bogra District. Bogra: Tajma Art Press.

31. Shah, D., \& Panigrahi, S. (2015), Determinants of participation of women in Self-Help Groups

32. (SGHs) and credit delivery from formal and informal sources to BPL households in Odisha, Indian Journal of Agricultural Economics, 70(3), 405 - 416.

33. Sirak, M., \& Rice, J.C. 1994. Logistic regression: An Introduction. In: Thompson, B. (Ed.). Advances in Social Science Methodology. Greenwich, CT: JAI Press.

34. Yusuf, M. O., Shirazi, N. S., \& Ghani, G. M. (2013). The Impact of Pakistan Poverty Alleviation Fund on Poverty in Pakistan: An Empirical Analysis Middle-East Journal of Scientific Research 13 (10): $1335-1344$.

35. Wooldridge, J. (2002). Econometrics analysis of cross section and panel data. Cambridge. MA USA: MIT Press. 